\title{
PENGARUH STRATEGI PEMBELAJARAN DAN KOMUNIKASI INTERPERSONAL TERHADAP HASIL BELAJAR BAHASA INDONESIA SISWA
}

\author{
Sabda Hidayah ${ }^{1}$, Mukhtar ${ }^{2}$, Rosmawaty ${ }^{3}$ \\ Guru SMP Negeri 1 Selesai, Sumatera Utara, \\ ${ }^{2,3}$ Program Pascasarjana Universitas Negeri Medan \\ sabda_hidayah@gmail.com ${ }^{1}$,mukhtardr.mt@gmail.com ${ }^{2}$
}

\begin{abstract}
Abstrak: Penelitian ini bertujuan (1) untuk mengetahui hasil belajar bahasa Indonesia siswa yang diajar dengan menggunakan strategi pembelajaran pemodelan lebih tinggi daripada siswa yang diajar dengan menggunakan strategi pembelajaran komunikatif, (2) untuk mengetahui hasil belajar bahasa Indonesia siswa yang komunikasi interpersonal tinggi lebih tinggi daripada siswa yang komunikasi interpersonal rendah, (3) untuk mengetahui interaksi antara strategi pembelajaran dengan komunikasi interpersonal terhadap hasil belajar bahasa Indonesia. Teтиaan penelitian menunjukkan bahwa (1) hasil belajar bahasa Indonesia siswa yang diajar dengan strategi pembelajaran pemodelan lebih tinggi dari hasil belajar siswa yang diajar dengan strategi pembelajaran komunikatif, dengan $F_{\text {hitung }}=3,38>F_{\text {tabel }}=2,6$, (2) hasil belajar bahasa Indonesia siswa komunikasi interpersonal tinggi lebih tinggi dari hasil belajar siswa komunikasi interpersonal rendah, dengan $F_{\text {hitung }}=29,62>F_{\text {tabel }}=2,67$, (3) terdapat interaksi antara strategi pembelajaran dan komunikasi interpersonal terhadap hasil belajar bahasa Indonesia, dengan $F_{\text {hitung }}=29,62>F_{\text {tabel }}=2,67$.
\end{abstract}

Kata Kunci: Strategi Pembelajaran, Komunikasi Interpersonal, Hasil Belajar Bahasa Indonesia

Abstract: This study aims (1) to find out the learning outcomes of Indonesian students who are taught using higher learning learning strategies than students who are taught using communicative learning strategies, (2) to find out the learning outcomes of Indonesian students who have higher interpersonal communication than students with low interpersonal communication, (3) to find out the interaction between learning strategies and interpersonal communication on the learning outcomes of Indonesian. Temuaan showed that (1) the results of Indonesian language learning students who are taught by modeling of higher learning strategy of learning outcomes of students taught by communicative learning strategy, with $F_{\text {count }}=3.38>F_{\text {table }}=2.6$, (2) the results of learning Indonesia high interpersonal communication students is higher than the results of students' interpersonal communication is low, with $F_{\text {count }}=29.62>F_{\text {table }}=2.67$, (3) there is no interaction between learning and interpersonal communication strategies towards learning outcomes Indonesian, with $F_{\text {count }}=29,62>F_{\text {table }}=2.67$.

Keywords: Learning Strategy, Interpersonal Communication, Indonesian Language Learning Results

\section{PENDAHULUAN}

Keterampilan berbahasa merupakan aspek kemampuan berbahasa yang menjadi sasaran tumpu pembelajaran bahasa. Oleh sebab itu, dalam dunia pendidikan para guru bahasa terus berupaya meningkatkan keberhasilan dalam pembelajaran bahasa melalui pencapaian kompetensi berbahasa, yakni menyimak, membaca, berbicara, dan menulis.

Kemampuan menyimak adalah salah satu unsur penting dalam keteampilan berbahasa. Tarigan (1985 : 19) meyataan bahwa menyimak adalah suatu proses kegiatan mendengarkan lambanglambang lisan dengan penuh perhatian, pemahaman, apresiasi, serta interprestasi, untuk memperoleh informasi, menangkapisi, serta memahami makna komunikasi yang telah disampaikan oleh pembicara melalui ujaran atau bahasa lisan. kemampuan menyimak itu adalah kemampuan, kesanggupan, kecakapan, siswa menerima dan memahami apa yang diucapkan atau dibaca orang lain. Urias (1987:21) juga memperjelas bahwa kemampuan menyimak merupakan proses belajar mengajar 
dan pembentukan kebiasaan yang terusmenerus.

Aspek keterampilan berbahasa yang kedua adalah membaca, menurut Tarigan (1985 :8) membaca adalah suatu proses memetik serta memahami arti atau makna yang terkandung di dalam bahasa tertulis. Membaca bukan hanya sekedar memahami lambang-lambang bahasa tulis saja, melainkan berusaha memahami, menerima, menolak, membandingkan, dan meyakini pendapat pengarang.

Berbicara bukan hanya sekadar pengucapan bunyi-bunyi atau kata-kata. Berbicara adalah suatu alat untuk mengomunikasikan gagasan-gagasan yang disusun serta dikembangkan sesuai dengan kebutuhan-kebutuhan sang pendengar atau penyimak. Keterampilan berbicara juga dituntut dalam berkomunikasi. Tarigan (1981:15) mengatakan bahwa berbicara adalah kemampuan mengucapkan bunyi-bunyi artikulasi atau kata-kata untuk mengekspresikan, menyatakan serta menyampaikan pikiran, gagasan dan perasaan.. Dipandang dari segi bahasa, menyimak dan berbicara dikategorikan sebagai keterampilan berbahasa lisan. Dari segi komunikasi, menyimak dan berbicara diklasifikasikan sebagai komunikasi lisan. Melalui berbicara orang menyampaikan informasi melalui ujaran kepada orang lain. Melalui menyimak orang menerima informasi dari orang lain. Kegiatan berbicara selalu diikuti kegiatan menyimak atau kegiatan menyimak pasti ada di dalam kegiatan berbicara.

Aspek keterampilan berbahasa yang keempat adalah menulis, menurut Tarigan (1986: 15), menulis adalah kegiatan menuangkan ide atau gagasan dengan menggunakan bahasa tulis sebagai media penyampai. Menulis pada dasarnya merupakan proses perkembangan.proses itu menuntut sebuah pengalaman, waktu, kesempatan, latihan, keterampilan-keterampilan khusus, dan pembelajaran yang diberikan dengan tepat dan sistematis.

Hasil belajar bahasa Indonesia yang masih relatif rendah dan ketidakmampuan siswa dalam mencapai kompetensi membaca puisi dan buku cerita anak di SMP Negeri 1 dan SMP Negeri 2 Selesai, disebabkan kebanyakan guru mengajar dengan menggunakan satu strategi pembelajaran berupa strategi pembelajaran konvensional dengan metode ceramah dan latihan saja, guru yang mendominasi proses belajar mengajar dan siswa tidak diaktifkan dalam suasana pembelajaran yang dapat memotivasi siswa dalam belajar. Kenyataannya dalam praktik pembelajaran bahasa Indonesia yang telah dilaksanakan, guru beranggapan bahwa proses dan isi mata pelajaran tidak begitu penting. Bahkan menurut Sanjaya (2007) pembelajaran mata pelajaran bahasa tidak diarahkan untuk mengembangkan kemampuan berkomunikasi, karena yang dipelajari lebih banyak bahasa sebagai ilmu bukan sebagai alat komunikasi.

Pengajaran akan lebih baik jika guru mengaitkan materi yang diajarkan dengan situasi dunia nyata kehidupan siswa dan mendorong siswa membuat hubungan antara pengetahuan yang dimilikinya dengan penerapannya dalam kehidupan mereka sebagai anggota keluarga dan anggota masyarakat, sebagai contoh dalam pembacaan cerita anak siswa dapat merefleksikan hal-hal positif yang diperoleh dari cerita yang dibaca dalam kehidupan sehari-hari mereka. Dengan demikian proses pembelajaran berlangsung alamiah dalam bentuk kegiatan siswa bukan transfer pengetahuan langsung dari guru ke siswa (Nurhadi, 2002).

\section{Hakikat Strategi Pembelajaran Komunikatif}

Menurut teori linguistik sebagai salah satu teori yang mendasari strategi komunikatif, belajar bahasa bukan sekedar belajar kaidah gramatikal serta keterampilan memakai kaidah itu dalam bentuk kalimat, melainkan lebih jauh daripada itu, belajar bahasa berarti berusaha menggunakan kalimat-kalimat itu sebagai sarana komunikasi dalam pengertian sesuai dengan situasi serta tutur yang berlaku dalam masyarakat penutur asli bahasa tersebut. (Purwo, 1990).

$$
\text { Strategi komunikatif dalam }
$$
pembelajaran bahasa berawal dari suatu teori yang berlandaskan bahasa sebagai komunikasi. Teori strategi komunikatif dalam pembelajaran bahasa sebenarnya telah ada sejak abad ke-4 meskipun terus menerus mengalami pergantian nama hingga abad ke-20. Menurut Purwo (1990) strategi komunikatif lebih mengutamakan kelancaran berkomunikasi atau penggunaan bahasa. Strategi ini memiliki pandangan bahwa keterampilan lisan harus diajarkan lebih dahulu sebelum keterampilan tulis. Strategi pembelajaran komunikatif bersumber dari teori pembelajaran humanistik. Tujuan utama dari humanisme dapat dijabarkan 
sebagai perkembangan dari aktualisasi diri manusia.

Dalam humanisme, belajar adalah proses yang berpusat pada pelajar dan dipersonalisasikan, dan peran pendidik adalah sebagai seorang fasilitator. Afeksi dan kebutuhan kognitif adalah kuncinya, dan tujuannya adalah untuk membangun manusia yang dapat mengaktualisasikan diri dalam lingkungan yang kooperatif dan suportif. Menurut Rifa'i dan Catharina (2009) pendekatan humanistik mengkombinasikan metode pembelajaran individual dan kelompok. pendidik memiliki status kesetaraan dengan peserta didik. Pendekatan humanistik memelihara kebebasan peserta didik untuk tumbuh dan melindungi peserta didik dari tekanan keluarga dan masyarakat.

Littlewood (1983) menyatakan ada empat macam tujuan strategi komunikatif sebagai berikut: (1) menciptakan suatu konteks yang menunjang pembelajaran, (2) mengadakan atau menetapkan "praktek tugas keseluruhan", (3) membolehkan atau mengizinkan pembelajaran alamiah, dan (4) menumbuhkan dan meningkatkan motivasi. Kemudian Canale dan Swain (dalam Tarigan, 1991) mengemukakan empat kompetensi komunikatif yaitu: (1) kompetensi gramatikal, mengacu pada kompetensi linguistik, (2) kompetensi sosiolinguistik, mengacu pada pemahaman konteks sosial tempat berlangsungnya komunikasi, termasuk hubungan, peranan, pembagian informasi dan tujuan interaksi komunikatif, seseorang dapat menggunakan bahasa secara baik, wajar, pragmatis, dan sesuai dengan konteks sosial pemakaian bahasa. (3) kompetensi wacana, mengacu pada interpretasi wacana atau struktur bahasa yang lebih besar dari kalimat, kompetensi wacana adalah kemampuan untuk memberikan interpretasi tentang topik, paragraf, bab, atau buku, dan (4) kompetensi strategik, mengacu pada pelekukakan strategi-strategi yang dipakai oleh para komunikator untuk memprakarsai, mengakhiri, memelihara, mereperasi, dan mengarahkan kembali komunikasi.

Tarigan (1991) mengatakan strategi komunikatif pada hakikatnya berorientasi pada fungsi bahasa sebagai alat komunikasi. Savigno (dalam Syahruddin, 1989) mengatakan tujuan pembelajaran strategi komunikatif adalah mengembangkan kompetensi komunikatif yang meliputi kompetensi gramatikal, kompetensi sosioliguistik, kompetensi wacana, dan kompetensi strategi. Menurut Nababan (1993) dalam strategi komunikatif ada 2 hal yang paling mendasar, yaitu: (1) kebermaknaan dari setiap bentuk bahasa yang dipelajari, dimana dalam mempelajari bahasa semua bentuk bahasa seperti: kata, frase, dan kalimat dan struktur bahasa seperti: urutan kata, imbuhan, dan kategori-kategori struktur, harus dikaitkan dengan arti atau makna, karena bahasa adalah pengungkapan ide, konsep, atau nosi, dan (2) bahwa bentuk, ragam, dan makna bahasa berhubungan dan terkait dengan situasi dan konteks bahasa itu, dimana bentuk dan makna bahasa itu tergantung pada faktor-faktor penentu yang ada dalam situasi dan konteks penggunaan bahasa itu.

Finocchiaro dan Brumfit (dalam Suwarna, 2002) menyatakan beberapa karakteristik strategi komunikatif yaitu: (1) mengembangkan keterampilan komunikasi siswa, (2) menekankan pada makna secara utuh dan fungsional, penyajian bahan tidak terpotong-potong dalam satuan-satuan lepas, (3) berorientasi pada konteks, (4) mempertajam kepekaan sosial, (5) belajar bahasa adalah belajar berkomunikasi, (6) komunikasi yang efektif merupakan tuntutan, (7) latihan komunikasi dimulai sejak permulaan belajar bahasa, (8) kompetensi komunikatif merupakan tujuan utama, (9) urutan pembelajaran tidak selalu linier, (10) siswa sebagai pusat belajar, (11) kesalahan berbahasa merupakan sesuatu yang wajar, dan (12) materi senantiasa melibatkan aspek linguistik, makna fungsional dan makna sosial. Sebagaimana yang dikatakan oleh Littlewood (1983) bahwa bahasa tidak hanya dilihat dari segi makna fungsionalnya tetapi juga makna sosialnya.

\section{Hakikat Strategi Pembelajaran Pemodelan}

Strategi pembelajaran pemodelan merupakan salah satu bentuk strategi pembelajaran kontekstual. Pemodelan (modeling) adalah membahasakan yang dipikirkan, memdemonstrasi bagaimana guru menghendaki siswanya untuk belajar dan melakukan sesuatu. Dalam pembelajaran kontekstual, Guru bukan satu-satunya model. Model bisa dirancang dengan melibatkan siswa atau bisa juga mendatangkan dari luar. Pemodelan merupakan proses penampilan suatu contoh agar orang lain berpikir, bekerja dan belajar dan mengerjakan apa yang guru inginkan agar siswa mengerjakannya 
Strategi pembelajaran pemodelan merupakan bagian atau cara yang penting dari belajar melalui proses sosial. Belajar sosial menjadi bagian rumpun strategi pembelajaran sosial (the social family) yang menggambarkan bahwa perilaku bekerjasama tidak hanya merupakan pemberian semangat sosial tetapi juga merupakan bagian pengembangan kemampuan intelektual. Melalui belajar dalam proses sosial, siswa akan menyesuaikan tingkah lakunya sesuai dengan peran sosial yang telah dipelajarinya.

Menurut Bandura dan Walters, seperti yang dikemukakan Sarwono (2001), ada tiga mcam pengaruh efek tingkah laku siswa, yaitu: (1) efek pemodelan (modeling effect) yaitu siswa melakukan tingkah laku baru melalui asosiasi-asosiasi sehingga sesuai dengan tingkah laku model, (2) efek penghambat (inhibition) dan menghapus hambatan (disinhibition) merupakan tingkah laku model yang diterima siswa tidak langsung ditiru, tetapi diamati oleh siswa sehingga timbul tingkah laku model yang ditirunya, (3) efek kemudahan (fascilitation effects) dimana tingkah laku yang dipelajari oleh siswa sebelum mengamati model dan muncul kembali setelah siswa mengamati tingkah laku dari pemodelan itu.

\section{Hakikat Komunikasi Interpersonal}

Dalam berkomunikasi dengan orang lain, tidak saja dituntut untuk menguasai gramatika dari suatu bahasa, tetapi juga dibutuhkan pengetahuan dalam berkomunikasi dengan orang lain yang disebut juga komunikasi interpersonal. Menurut Muhammad (2004) komunikasi interpersonal merupakan proses pertukaran informasi di antara seseorang dengan paling kurang seorang lainnya atau biasanya di antara dua orang yang dapat langsung diketahui balikannya. Menurut Devito (2002) komunikasi interpersonal adalah penyampaian pesan oleh satu orang dan penerimaan pesan oleh orang lain atau sekelompok kecil orang, dengan berbagai dampaknya dan dengan peluang untuk memberikan umpan balik segera, sedangkan Mulyana (2000) menyatakan bahwa komunikasi interpersonal adalah komunikasi antara orangorang secara tatap muka, yang memungkinkan setiap pesertanya menangkap reaksi orang lain secara langsung, baik secara verbal atau nonverbal. Komunikasi interpersonal ini adalah komunikasi yang hanya dua orang, seperti suami istri, dua sejawat, dua sahabat dekat, guru-murid dan sebagainya. Dari berbagai pendapat para ahli tentang pengertian komunikasi interpersonal, Effendy (2003) menyimpulkan pada hakekatnya komunikasi interpersonal adalah komunikasi antar komunikator dengan komunikan, komunikasi jenis ini dianggap paling efektif dalam upaya mengubah sikap, pendapat atau perilaku seseorang, karena sifatnya yang dialogis berupa percakapan. Arus balik bersifat langsung, komunikator mengetahui tanggapan komunikan ketika itu juga.

West dan Turner (2008) menyatakan komunikasi interpersonal merujuk pada komunikasi yang terjadi secara langsung antara dua orang. konteks interpersonal banyak membahas tentang bagaimana suatau hubungan dimulai, mempertahankan suatau hubungan, dan keretakan suatau hubungan. Pada saat komunikasi dilancarkan, komunikator mengetahui secara pasti apakah komunikasinya positif atau negatif, berhasil atau tidaknya, jika ia dapat memberikan kesempatan pada komunikan untuk bertanya seluas-luasnya. Komunikasi Interpersonal menuntut berkomunikasi dengan orang lain. Komunikasi jenis ini dibagi lagi menjadi komunikasi diadik, komunikasi publik, dan komunikasi kelompok kecil (Rahmad, 2001).

Berdasarkan pembatasan masalah maka masalah penelitian ini dapat dirumuskan sebagai berikut:

1. Apakah kelompok siswa yang dibelajarkan dengan strategi pembelajaran pemodelan (dengan model langsung) memperoleh hasil belajar bahasa Indonesia (membaca puisi dan buku cerita anak) lebih tinggi dibandingkan dengan kelompok siswa yang dibelajarkan dengan strategi pembelajaran komunikatif?

2. Apakah kelompok siswa yang memiliki komunikasi interpersonal tinggi memperoleh hasil belajar bahasa Indonesia (membaca puisi dan buku cerita anak) lebih tinggi dibandingkan dengan kelompok siswa yang memiliki komunikasi interpersonal rendah?

3. Apakah terdapat interaksi antara strategi pembelajaran dan komunikasi interpersonal terhadap hasil belajar bahasa Indonesia (membaca puisi dan buku cerita anak)?

\section{METODE}

Penelitian ini dilakukan di SMP Negeri 1 Selesai dan SMP Negeri 2 Selesai. Populasi dalam penelitian ini adalah seluruh siswa kelas 
VII SMP Negeri 1 Selesai, berjumlah 317 orang siswa dengan jumlah kelas 8 kelas masingmasing kelas rata-rata terdiri dari 40 orang siswa, dan SMP Negeri 2 Selesai dengan jumlah 118 orang siswa dari 3 kelas masingmasing kelas rata-rata terdiri dari 36 sampai 40 orang siswa.

Metode yang digunakan dalam penelitian ini adalah eksperimental semu (quasi-experimental design) dengan melakukan eksperimen di dalam kelas yang sudah tersedia sebagaimana adanya, tanpa melakukan perubahan situasi kelas dan jadwal pembelajaran. Perlakuan dilaksanakan pada pembelajaran bahasa Indonesia dengan menggunakan strategi pembelajaran pemodelan yang dibandingkan dengan strategi pembelajaran komunikatif, dilaksanakan pada kelas perlakuan yang telah ditetapkan. Pada masing-masing kelas terdapat siswa yang memiliki komunikasi interpersonal tinggi dan komunikasi interpersonal rendah berdasarkan hasil analisis tes. Guru yang ditetapkan untuk melakukan pembelajaran dengan strategi pembelajaran pemodelan maupun komunikatif diberikan petunjuk khusus mengenai cara dan langkah-langkah dalam penyajian materi pelajaran.

Desain penelitian yang digunakan adalah desain faktorial $2 \times 2$, seperti pada Tabel 3..1 yang membandingkan strategi pembelajaran pemodelan dengan strategi pembelajaran komunikatif terhadap komunikasi interpersonal tinggi dan komunikasi interpersonal rendah.

Tabel 1. Desain Faktorial $2 \times 2$

\begin{tabular}{|l|c|c|}
\hline $\begin{array}{c}\text { Komunikasi } \\
\text { Interpersonal } \\
(\mathrm{B})\end{array}$ & $\begin{array}{c}|c| \\
\text { Strategi Pembelajaran }(\mathrm{A}) \\
\left(\mathrm{A}_{1}\right)\end{array}$ & $\begin{array}{c}\text { Komunikatif } \\
\left(\mathrm{A}_{2}\right)\end{array}$ \\
\hline Tinggi $\left(\mathrm{B}_{1}\right)$ & $\mathrm{A}_{1} \mathrm{~B}_{1}$ & $\mathrm{~A}_{2} \mathrm{~B}_{1}$ \\
\hline $\begin{array}{l}\text { Rendah } \\
\left(\mathrm{B}_{2}\right)\end{array}$ & $\mathrm{A}_{1} \mathrm{~B}_{2}$ & $\mathrm{~A}_{2} \mathrm{~B}_{2}$ \\
\hline
\end{tabular}

Keterangan :

$\mathrm{A}=$ Strategi pembelajaran

$\mathrm{B}=$ Komunikasi interpersonal

$\mathrm{A}_{1}=$ Strategi pembelajaran pemodelan

$\mathrm{A}_{2}=$ Strategi pembelajaran komunikatif

$\mathrm{B}_{1}=$ Komunikasi interpersonal tinggi

$\mathrm{B}_{2}=$ Komunikasi interpersonal rendah
$\mathrm{A}_{1} \mathrm{~B}_{1}=$ Hasil belajar bahasa Indonesia siswa yang dibelajarkan dengan menggunakan strategi pembelajaran pemodelan pada siswa dengan komunikasi interpersonal tinggi

$\mathrm{A}_{1} \mathrm{~B}_{2}=$ Hasil belajar bahasa Indonesia siswa yang dibelajarkan dengan menggunakan strategi pembelajaran pemodelan pada siswa dengan komunikasi interpersonal rendah.

$\mathrm{A}_{2} \mathrm{~B}_{1}=$ Hasil belajar bahasa Indonesia siswa yang dibelajarkan dengan menggunakan strategi pembelajaran komunikatif pada siswa dengan komunikasi interpersonal tinggi.

$\mathrm{A}_{2} \mathrm{~B}_{2}=$ Hasil belajar bahasa Indonesia siswa yang dibelajarkan dengan menggunakan strategi pembelajaran komunikatif pada siswa dengan komunikasi interpersonal rendah.

Teknik analisis data dalam penelitian ini menggunakan analisis deskriptif dan analisis inferensial. Teknik analisis deskriptif dimaksudkan untuk mendeskripsikan data penelitian melipuiti mean, median, standard deviasi dan kecenderungan data. Data yang telah diperoleh selanjutnya disajikan dalam bentuk tabel distribusi frekuensi dan histogram. Teknik analisis inferensial digunakan untuk menguji hipotesis penelitian dengan menggunakan teknik analisis varians (ANAVA) dua jalur.

Untuk menggunakan ANAVA dua jalur perlu dipenuhi beberapa syarat yaitu: (1) data yang digunakan harus berdistribusi normal, untuk menguji normalitas data digunakan uji Liliefors, dan (2) data harus memiliki varians populasi homogen, untuk menguji homogenitas varians antara kedua strategi pembelajaran dan antara komunikasi interpersonal digunakan uji Fisher (uji F) dan untuk uji homogenitas antara semua kelompok digunakan uji Bartlet. Karena uji Anava dua jalur signifikan dan jumlah sampel dari masing-masing sel dalam rancangan penelitian tidak sama, maka dilakukan uji lanjut menggunakan Uji Scheffe. Semua pengujian dilakukan pada taraf 0,05 .

Rumusan hipotesis statistik dalam penelitian ini adalah sebagai berikut:

a. Hipotesis pertama :

$$
\begin{array}{ll}
\text { Ho } & : \mu_{A 1} \leq \mu_{A 2} \\
\text { H1 } & : \mu_{A 1}>\mu_{A 2}
\end{array}
$$


b. Hipotesis kedua :

$$
\begin{array}{ll}
\text { Ho } & : \mu_{B 1} \leq \mu_{B 2} \\
\text { H1 } & : \mu_{B 1}>\mu_{B 2}
\end{array}
$$

c. Hipotesis ketiga :

Ho: $\mathrm{A} \times \mathrm{B}=0$

$\mathrm{H} 1: \mathrm{A} \times \mathrm{B} \neq 0$

Keterangan :

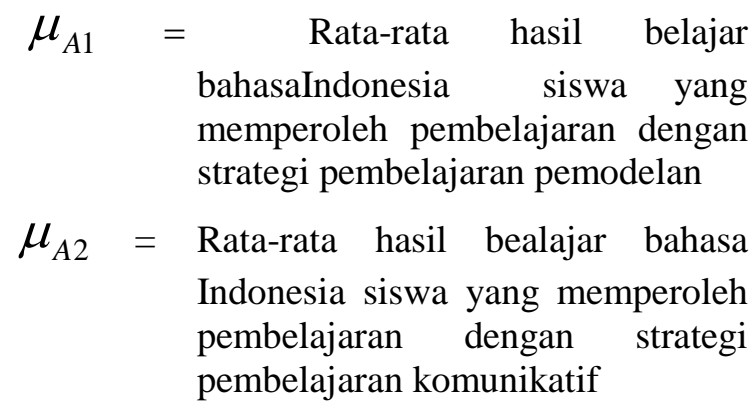

\begin{tabular}{|c|c|c|c|c|}
\hline \multirow{2}{*}{\multicolumn{2}{|c|}{$\begin{array}{l}\text { RINGKASAN } \\
\text { DATA }\end{array}$}} & \multicolumn{2}{|c|}{ Strategi pembelajaran } & \multirow{2}{*}{ Total } \\
\hline & & Pemodelan & Komunikatif & \\
\hline \multirow{2}{*}{$\begin{array}{l}\text { Komunikasi } \\
\text { interpersonal }\end{array}$} & Tinggi & $\begin{array}{c}\mathrm{n}_{1}=34 \\
\overline{\mathrm{X}}_{1}=29,00 \\
\mathrm{~s}_{1}=2,80\end{array}$ & $\begin{array}{c}\mathrm{n}_{3}=34 \\
\overline{\mathrm{X}}_{3}=27,56 \\
\mathrm{~s}_{3}=2,38\end{array}$ & $\begin{array}{c}\mathrm{N}_{1,3}=68 \\
\bar{X}_{1,3}=27,92 \\
\mathrm{~s}_{1,3}=2,99\end{array}$ \\
\hline & Rendah & $\begin{array}{c}\mathrm{n}_{2}=41 \\
\overline{\mathrm{X}}_{3}=25,94 \\
\mathrm{~s}_{3}=3,18\end{array}$ & $\begin{aligned} \mathrm{n}_{4} & =44 \\
\overline{\mathrm{X}}_{4} & =26,54 \\
\mathrm{~s}_{4} & =2,76\end{aligned}$ & $\begin{array}{c}\mathrm{N}_{2,4}=85 \\
\overline{\mathrm{X}}_{2,4}=26,64 \\
\mathrm{~s}_{2,4}=3,11\end{array}$ \\
\hline \multicolumn{2}{|c|}{ Total } & $\begin{array}{c}\mathrm{N}_{1,2}=75 \\
\overline{\mathrm{X}}_{1,2}=27,46 \\
\mathrm{~S}_{1,2}=3,53\end{array}$ & $\begin{array}{c}\mathrm{N}_{3,4}=78 \\
\bar{X}_{3,4}=27,00 \\
\mathrm{~s}_{3,4}=2,66\end{array}$ & $\begin{aligned} \mathrm{N}_{\mathrm{g}} & =153 \\
\bar{X}_{\mathrm{g}} & =27,89 \\
\mathrm{~s}_{\mathrm{g}} & =3,18\end{aligned}$ \\
\hline
\end{tabular}

$$
\begin{aligned}
\mu_{B 1}= & \begin{array}{l}
\text { Rata-rata hasil belajar bahasa } \\
\text { Indonesia siswa yang memiliki } \\
\text { komunikasi interpersonal tinggi. }
\end{array} \\
\mu_{B 2}= & \begin{array}{l}
\text { Rata-rata hasil belajar bahasa } \\
\text { Indonesia siswa yang memiliki } \\
\text { komunikasi interpersonal rendah. }
\end{array} \\
\mathrm{A} \times \mathrm{B}= & \begin{array}{l}
\text { Rata-rata interaksi antara strategi } \\
\text { pembelajaran dengan komunikasi } \\
\text { interpersonal }
\end{array}
\end{aligned}
$$

\section{HASIL PENELITIAN}

Berdasarkan deskriptif hasil belajar ekonomi diperoleh data hasil belajar bahasa Indonesia siswa pada Tabel 2. dengan menggunakan rangkuman analisis deskriptif sebagai berikut:

Tabel 2. Rangkuman Data Hasil Perhitungan Analisis Deskriptif.

Untuk keperluan pengujian hipotesis dengan menggunakan teknik analisis varian dua jalur (ANAVA) faktorial 2x2 dan uji lanjut dengan menggunakan uji Scheffe diperlukan harga rata-rata tiap kelompok, selanjutnya harga rata-rata tiap kelompok diolah dengan ANAVA 2 jalur faktorial 2 x 2, dan diperoleh hasil analisis seperti ditunjukkan pada Tabel 3.

Tabel 3. Ringkasan Hasil Perhitungan ANAVA Faktorial $2 \times 2$

\begin{tabular}{|l|c|c|c|c|c|c|}
\hline \multicolumn{1}{|c|}{ Sumber Varians } & JK & $\mathbf{d b}$ & $\mathbf{K T}$ & $\mathbf{F}_{\text {hitung }}$ & $\begin{array}{c}\mathbf{F}_{\text {tabel }} \\
(\mathbf{\alpha = 0 , 0 5})\end{array}$ & Ket. \\
\hline Strategi & 27.7 & 1 & 27.7 & 3.38 & 2.67 & Signifikan \\
Komunikasi Interpersonal & 186.2 & 1 & 186.2 & 22.74 & 2.67 & Signifikan \\
Interaksi & 242.6 & 1 & 242.6 & 29.62 & 2.67 & Signifikan \\
Dalam kelompok (galat) & 1261.1 & 150 & 8.19 & - & - & - \\
\hline \multicolumn{1}{|c|}{ Total } & 1548.4 & 153 & - & - & - & - \\
\hline
\end{tabular}

Hasil analisis yang disajikan pada Tabel 3 merupakan ringkasan hasil perhitungan ANAVA faktorial 2 × 2 untuk sampel penelitian keseluruhan dari dua sekolah dengan jumlah sampel 153 orang siswa.
Perbedaan Hasil Belajar Bahasa Indonesia Antara siswa yang Diajar dengan Strategi Pembelajaran Pemodelan dan Komunikatif Pengujian dilakukan terhadap hipotesis statistik yang dirumuskan sebagai berikut.

Ho: $\quad \mu_{A 1} \leq \mu_{A 2}$ 
Ha : $\quad \mu_{A 1}>\mu_{A 2}$

Keterangan :

$\mu_{A 1}=$ Rata-rata hasil belajar Bahasa Indonesia siswa yang diajar dengan strategi pembelajaran pemodelan

$\mu_{A 2}=$ Rata-rata hasil belajar bahasa Indonesia siswa yang diajar dengan strategi pembelajaran komunikatif.

Dari hasil perhitungan analisis perbedaan hasil belajar Bahasa Indonesia siswa yang diajar dengan strategi pembelajaran pemodelan sebesar $\bar{X}=27,46$ dan strategi komunikatif $\bar{X}=27,00$ didapat harga $F_{h}$ sebesar 3,38 dan harga $F_{t}$ adalah 2,67. Karena $\mathrm{F}_{\mathrm{h}}$ 3,38 > 2,67, maka Ho ditolak, hipotesis penelitian yang menyatakan: hasil belajar Bahasa Indonesia siswa yang diajar dengan strategi pembelajaran pemodelan lebih tinggi daripada hasil hasil belajar Bahasa Indonesia siswa yang diajar dengan strategi pembelajaran komunikatif pada taraf kepercayaan $\alpha=0,05$ teruji kebenarannya.

\section{Perbedaan Hasil Belajar Bahasa Indonesia Antara Siswa dengan Siswa Dengan Komunikasi Interpersonal Tinggi dan Siswa Dengan Komunikasi Interpersonal Rendah.}

Perbedan hasil belajar Bahasa

Indonesia dari siswa dengan komunikasi interpersonal tinggi dan siswa yang dengan komunikasi interpersonal rendah dilakukan dengan analisis varian (ANAVA). Pengujian dilakukan terhadap hipotesis yang dirumuskan sebagai berikut.

Hipotesis yang dirumuskan berbentuk :

Ho: $\quad \mu_{B 1} \leq \mu_{B 2}$

Ha : $\mu_{B 1}>\mu_{B 2}$

Keterangan :

$$
\begin{aligned}
\mu_{B 1}= & \text { Rata-rata hasil belajar Bahasa } \\
& \text { Indonesia siswa dengan komunikasi } \\
& \text { interpersonal tinggi. }
\end{aligned}
$$

$\mu_{B 2}=$ Rata-rata hasil belajar Bahasa Indonesia siswa dengan komunikasi interpersonal rendah.

Hasil perhitungan analisis varian tentang perbedaan hasil belajar Bahasa Indonesia antara siswa yang memiliki dengan komunikasi interpersonal tinggi dan siswa dengan komunikasi interpersonal rendah dengan rata-rata $\bar{X}=27,92, \bar{X}=26,64$. Berdasarkan tabel 27 dapat dihitung $F_{h}=22,74$ dan harga tabel untuk $\alpha=0,05$ dengan dk (1:) diperoleh $\mathrm{F}=2,67$ sehingga dapat dinyatakan $F_{h}(22,74)>F_{t}(2,67)$. Dengan demikian Ho ditolak, hipotesis penelitian yang menyatakan: hasil belajar Bahasa Indonesia siswa dengan komunikasi interpersonal tinggi lebih tinggi daripada hasil belajar siswa yang dengan komunikasi interpersonal rendah pada taraf kepercayaan $\alpha=0,05$ teruji kebenarannya

\section{Interaksi Antara Strategi Pembelajaran dan Komunikasi Interpersonal Terhadap Hasil Belajar Bahasa Indonesia}

Pengujian dilakukan terhadap hipotesis statistik yang dirumuskan sebagai berikut :

Ho : interaksi $\mathrm{A} \times \mathrm{B}=0$

$\mathrm{Ha}$ : interaksi $\mathrm{A} \times \mathrm{B} \neq 0$

Keterangan:

A $=$ Strategi Pembelajaran

$\mathrm{B}=$ Komunikasi interpersonal

Berdasarkan rata-rata hasil belajar

Bahasa Indonesia untuk setiap kelompok pembelajaran yaitu, untuk strategi pembelajaran pemodelan pada siswa dengan komunikasi interpersonal tinggi $\bar{X}=29,00$, untuk strategi pembelajaran pemodelan pada siswa dengan komunikasi interpersonal rendah $\bar{X}=25,94$, untuk strategi pembelajaran komunikatif pada siswa dengan komunikasi interpersonal tinggi $\overline{\mathrm{X}}=27,56$ dan untuk strategi pembelajaran Komunikatif pada siswa dengan komunikasi interpersonal rendah $\bar{X}=26,54$ hasil perhitungan ANAVA fatorial $2 \times 2$ diperoleh hasil perhitungan $F_{h}=29,62$ dengan harga tabel $\mathrm{F}_{\mathrm{t}}$ untuk taraf kepercayaan $(\alpha)$ sebesar 0,05 dengan $\mathrm{dk}=(3: 152)$ adalah $\mathrm{F}_{\mathrm{t}(0,05)}=2,67$ sehingga dapat dinyatakan $F_{h}(29,62)>F_{t}$ $(2,67)$. Dengan demikian Ho ditolak, hipotesis penelitian yang menyatakan terdapat interaksi antara strategi pembelajaran dan komunikasi interpersonal terhadap hasil belajar Bahasa Indonesia teruji kebenarannya pada taraf signifikan 0,05. Interaksi antara strategi pembelajaran dapat divisualisasikan secara grafis pada Gambar 1 berikut. 


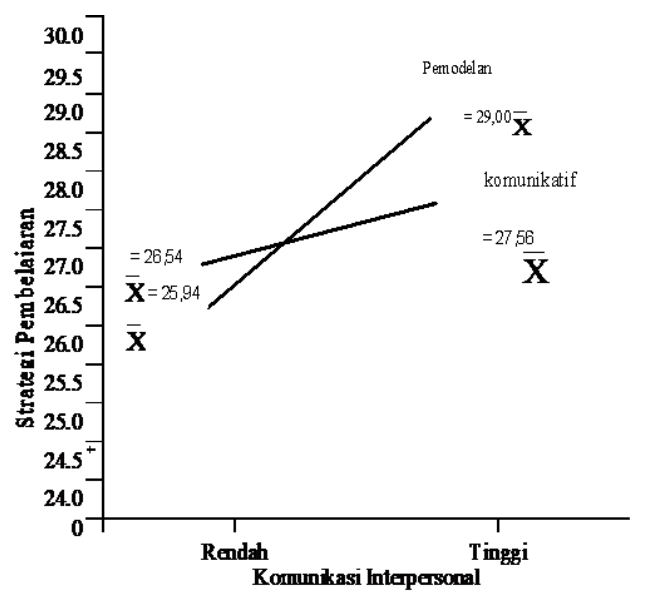

Gambar 1. Interaksi Strategi Pembelajaran dan Perbedaan Komunikasi interpersonal Terhadap Hasil Belajar Bahasa Indonesia

Karena terdapat interaksi antara strategi pembelajaran dengan perbedaan komunikasi interpersonal maka perlu dilakukan uji Schefee, hasil pengujian dengan menggunakan uji Scheffee dapat dilihat dalam Tabel 4.

Tabel 4. Ringkasan Hasil Uji Lanjut Menggunakan Uji Scheffe

\begin{tabular}{|c|c|c|c|c|c|}
\hline \multirow{2}{*}{$\begin{array}{l}\mathrm{N} \\
\mathrm{o}\end{array}$} & \multirow{2}{*}{\multicolumn{2}{|c|}{ Hipotesis Statistik }} & \multirow{2}{*}{$F_{\text {hitung }}$} & \multicolumn{2}{|c|}{$\mathrm{F}_{\text {tabel }}$} \\
\hline & & & & $\alpha=5 \%$ & $\alpha=1 \%$ \\
\hline 1 & Ho $: \mu_{\mathrm{A} 1 \mathrm{~B} 1}=\mu_{\mathrm{A} 2 \mathrm{~B} 1}$ & Ha: $\mu_{\mathrm{A} 1 \mathrm{~B} 1}>\mu_{\mathrm{A} 2 \mathrm{~B} 1}$ & 4.45 & 2,67 & 3,91 \\
\hline 2 & Ho $: \mu_{\mathrm{A} 1 \mathrm{~B} 1}=\mu_{1 \mathrm{~B} 2}$ & $\mathrm{Ha}: \mu_{\mathrm{A} 1 \mathrm{~B} 1>} \mu_{1 \mathrm{~B} 2}$ & 4,15 & 2,67 & 3,91 \\
\hline 3 & 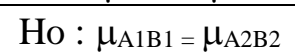 & $\mathrm{Ha}: \mu_{\mathrm{A} 1 \mathrm{~B} 1}>\mu_{\mathrm{A} 1 \mathrm{~B} 2}$ & 2.97 & 2,67 & 3,91 \\
\hline 4 & Ho $: \mu_{\mathrm{A} 1 \mathrm{~B} 2}=\mu_{\mathrm{A} 2 \mathrm{~B} 2}$ & $\mathrm{Ha}: \mu_{\mathrm{A} 1 \mathrm{~B} 2=\mu_{\mathrm{A} 2 \mathrm{~B} 2}}$ & 2.11 & 2,67 & 3,91 \\
\hline 5 & Ho $: \mu_{\mathrm{A} 2 \mathrm{~B} 1}=\mu_{\mathrm{A} 2 \mathrm{~B} 2}$ & $\mathrm{Ha}: \mu_{\mathrm{A} 2 \mathrm{~B} 1}=\mu_{\mathrm{A} 2 \mathrm{~B} 2}$ & 1,16 & 2,67 & 3,91 \\
\hline 6 & Ho $: \mu_{\mathrm{A} 2 \mathrm{~B} 1=\mu_{\mathrm{A} 1 \mathrm{~B} 2}}$ & $\mathrm{Ha}: \mu_{\mathrm{A} 2 \mathrm{~B} 1=\mu_{\mathrm{A} 1 \mathrm{~B} 2}}$ & 0.84 & 2,67 & 3,91 \\
\hline
\end{tabular}

\section{PEMBAHASAN}

Perbedaan Hasil Belajar Bahasa Indonesia antara Siswa yang Diajar dengan Strategi Pembelajaran Pemodelan dan Strategi Pembelajaran Komunikatif.

Dari hasil pengolahan data yang dilakukan terdapat perbedaan hasil belajar Bahasa Indonesia antara siswa yang diajar dengan strategi pemodelan dengan strategi pembelajaran komunikatif, yaitu rata-rata hasil belajar Bahasa Indonesia siswa yang diajar dengan strategi pemodelan lebih tinggi daripada rata-rata hasil belajar Bahasa Indonesia siswa yang diajar dengan strategi pembelajaran komunikatif. Kenyataan ini membuktikan bahwa strategi pemodelan lebih baik dalam meningkatkan pemahaman siswa dalam pembelajaran Bahasa Indonesia daripada penggunaan strategi pembelajaran komunikatif. Dengan demikian mengajarkan materi ajar Bahasa Indonesia untuk beberapa materi seperti membaca indah puisi dan menemukan realitas kehidupan anak dalam buku cerita anak lebih baik diajarkan dengan strategi pemodelan disbanding dengan strategi pembelajaran komunikatif.

Dalam strategi pemodelan memberikan peluang yang besar bagi seseorang untuk memberi contoh cara mengerjakan sesuatu.
Strategi pembelajaran pemodelan dapat dirancang dengan melibatkan siswa secara aktif, di mana siswa yang memiliki keahlian dapat ditunjuk untuk mendemonstrasikan keahliannya kepada teman-temannya (Sagala, 2003). Selain siswa, model hidup yang merupakan ahli di dalam bidang tertentu, atau orang yang memiliki profesi tertentu dan mereka sukses dalam profesinya tersebut, juga dapat dijadikan sebagai model dalam pembelajaran. Dengan mendatangkan orang yang memiliki profesi tertentu ini sebagai model dalam pembelajaran, maka siswa dapat mengetahui perilaku positif dari model dan pada akhirnya mau meniru perilaku model tersebut karena sudah mengetahui manfaat dari perilaku yang dicontohkan oleh model.

$$
\text { Strategi komunikatif dalam }
$$
pembelajaran mendukung teori yang dikemukakan oleh Finocchiaro dan Brumfit (dalam Suwarna, 2002) yang menyatakan beberapa karakteristik strategi pemodelan yaitu: (1) mengembangkan keterampilan komunikasi siswa, (2) menekankan pada makna secara utuh dan fungsional, penyajian bahan tidak terpotong-potong dalam satuan-satuan lepas, (3) berorientasi pada konteks, (4) mempertajam kepekaan sosial, (5) belajar bahasa adalah belajar berkomunikasi, (6) komunikasi yang 
efektif merupakan tuntutan, (7) latihan komunikasi dimulai sejak permulaan belajar bahasa, (8) kompetensi pemodelan merupakan tujuan utama, (9) urutan pembelajaran tidak selalu linier, (10) siswa sebagai pusat belajar, (11) kesalahan berbahasa merupakan sesuatu yang wajar, dan (12) materi senantiasa melibatkan aspek linguistik, makna fungsional dan makna sosial.

Teori yang dikemukakan di atas juga sejalan dengan pendapat Nababan (1993) yang menyatakan dalam strategi komunikatif ada 2 hal yang paling mendasar, yaitu: (1) kebermaknaan dari setiap bentuk bahasa yang dipelajari, dimana dalam mempelajari bahasa semua bentuk bahasa seperti: kata, frase, dan kalimat dan struktur bahasa seperti: urutan kata, imbuhan, dan kategori-kategori struktur, harus dikaitkan dengan arti atau makna, karena bahasa adalah pengungkapan ide, konsep, atau nosi, dan (2) bahwa bentuk, ragam, dan makna bahasa berhubungan dan terkait dengan situasi dan konteks bahasa itu, dimana bentuk dan makna bahasa itu tergantung pada faktor-faktor penentu yang ada dalam situasi dan konteks penggunaan bahasa itu. Pemodelan dicirikan oleh siswa yang bekerjasama satu dengan yang lainnya, paling sering secara berpasangan atau dalam kelompok kecil. Kegiatan ini merangsang struktur kognitif siswa untuk lebih memahami materi pelajaran secara alamiah sehingga dapat meningkatkan hasil belajar siswa.

Hasil penelitian yang menyatakan bahwa hasil belajar Bahasa Indonesia siswa yang dibelajarkan dengan strategi pembelajaran pemodelan lebih tinggi daripada hasil belajar siswa yang dibelajarkan dengan strategi pembelajaran komunikatif juga mendukung penelitian sebelumnya yang dilakukan oleh Susilawati (2005), dari penelitian ini disimpulkan bahwa terdapat perbedaan pengaruh antara strategi pembelajaran pemodelan dengan strategi pembelajaran kekspositori terhadap hasil belajar PPKn siswa. Penelitan serupa juga dilakukan oleh Usmaidar (2006) yang menyimpulkan bahwa terdapat perbedaan yang signifikan dalam hasil belajar geografi siswa yang diajarkan dengan strategi pembelajaran pemodelan jika dibandingkan dengan strategi pembelajaran ekspositori. Penelitian yang dilakukan Molina (2009) menyimpulkan hasil belajar kewirausaahaan siswa lebih tinggi jika diajar dengan strategi pembelajaran pemodelan daripada strategi pembelajaran ekspositori.

\section{Perbedaan Hasil Belajar Bahasa Indonesia Antara Siswa Yang Dengan Komunikasi Interpersonal Tinggi dengan Siswa Dengan Komunikasi Interpersonal Rendah}

Hasil penelitian menunjukkan bahwa rata-rata hasil belajar Bahasa Indonesia siswa dengan komunikasi interpersonal tinggi lebih tinggi dibandingkan hasil belajar Bahasa Indonesia siswa yang dengan komunikasi interpersonal rendah. Siswa yang mempunyai komunikasi interpersonal tinggi cenderung bersikap responsif dalam proses pembelajaran, siswa dengan kemampuan komunikasi interpersonal yang baik akan lebih mudah memahami konsep dan makna bahasa yang dipelajari, siswa akan lebih mudah mengkomunikasikan bahasa pada saat pembelajaran baik dalam bentuk lisan maupun tulisan. Kemudahan dalam berkomunikasi akan mempengaruhi pemahaman siswa dalam pembelajaran bahasa sehingga dapat meningkatkan prestasi belajar siswa.

Hasil penelitian ini mendukung teori yang dikemukakan oleh West dan Turner (2008) menyatakan komunikasi interpersonal merujuk pada komunikasi yang terjadi secara langsung antara dua orang. konteks interpersonal banyak membahas tentang bagaimana suatau hubungan dimulai, mempertahankan suatau hubungan, dan keretakan suatau hubungan. Pada saat komunikasi dilancarkan, komunikator mengetahui secara pasti apakah komunikasinya positif atau negatif, berhasil atau tidaknya, jika ia dapat memberikan kesempatan pada komunikan untuk bertanya seluas-luasnya. Komunikasi Interpersonal menuntut berkomunikasi dengan orang lain. Komunikasi jenis ini dibagi lagi menjadi komunikasi diadik, komunikasi publik, dan komunikasi kelompok kecil (Rahmad, 2001). Teori lain yang mendukung hasil penelitian ini dikemukakan oleh Muhammad (2004) ada beberapa tujuan dari perlunya komunikasi interpersonal pada diri seseorang. yaitu: (1) menemukan diri sendiri, salah satu tujuan komunikasi interpersonal adalah menemukan personal atau pribadi, bila kita terlibat dalam pertemuan interpersonal dengan orang lain kita belajar banyak sekali tentang diri kita maupun orang lain, (2) menemukan dunia luar, hanya komunikasi interpersonal menjadikan seseorang 
dapat memahami lebih banyak tentang dirinya dan orang lain yang berkomunikasi dengannya, (3) membentuk dan menjaga hubungan yang penuh arti, salah satu keinginan orang yang paling besar adalah membentuk dan memelihara hubungan dengan orang lain, banyak dari waktu manusia dipergunakan dalam komunikasi interpersonal diabadikan untuk membentuk dan menjaga hubungan sosial dengan orang lain, (4) merubah sikap dan tingkah laku, banyak waktu dipergunakan untuk mengubah sikap dan tingkah laku orang lain dengan pertemuan interpersonal ada beberapa cara tertentu yang dapat dilakukan, misalnya mencoba diet yang baru, membeli barang tertentu, melihat film, menulis membaca buku, memasuki bidang tertentu dan percaya bahwa sesuatu itu benar atau salah, (5) untuk bermain dan kesenangan, bermain mencakup semua aktivitas yang mempunyai tujuan utama adalah mencari kesenangan, berbicara dengan teman mengenai aktivitas kita pada waktu akhir pekan, berdiskusi mengenai olahraga, menceritakan cerita dan cerita lucu pada umumnya hal itu adalah merupakan pembicaraan yang untuk menghabiskan waktu yang tergolong sebagai komunikasi interpersonal, dan (6) untuk membantu dalam bidang tertentu, ahli-ahli kejiwaan, ahli psikologi klinis dan terapi menggunakkan komunikasi interpersonal dalam kegiatan profesional mereka untuk mengarahkan

\section{Interaksi Antara Strategi Pembelajaran Dan Komunikasi Interpersonal Dalam Mempengaruhi Hasil Belajar Bahasa Indonesia}

Temuan penelitian menunjukkan bahwa terdapat interaksi antara strategi pembelajaran dan perbedaan komunikasi interpersonal terhadap hasil belajar Bahasa Indonesia siswa. Siswa yang dengan komunikasi interpersonal tinggi dengan mengikuti strategi pembelajaran pemodelan lebih tinggi hasil belajarnya dibandingkan dengan siswa dengan komunikasi interpersonal rendah dengan strategi pembelajaran komunikatif. Demikian pula siswa yang dengan komunikasi interpersonal rendah dengan mengikuti strategi pembelajaran komunikatif memperoleh hasil belajar yang lebih tinggi, dibandingkan dengan siswa yang dengan komunikasi interpersonal tinggi dengan strategi pembelajaran komunikatif. Hal ini mengindikasikan adanya interaksi antara strategi pembelajaran dengan komunikasi interpersonal siswa terhadap hasil belajar Bahasa Indonesia.

Strategi pembelajaran komunikatif merupakan strategi pembelajaran yang menuntut adanya interaksi dua arah antara guru dan siswa, serta siswa dengan siswa. Guru hanya berperan sebagai fasilitator, sedangkan siswa bebas mengkomunikasikan pikirannya tanpa harus takut salah. Dengan jalan seperti ini maka siswa akan akan lebih mudah untuk menguasai komunikasi interpersonal dalam Bahasa Indonesia, makin tinggi komunikasi interpersonal maka hasil belajar Bahasa Indonesia yang diharapkan pun akan semakin baik pula, hal ini terjadi karena komunikasi interpersonal yang telah tersimpan di dalam long term memory siswa dapat difungsikan atau dipergunakan dalam proses berkomunikasi. Sebaliknya, makin sedikit komunikasi interpersonal, maka makin sulit bagi siswa untuk melakukan proses komunikasi dan secara otomatis hasil yang belajar yang diperoleh tidak sesuai dengan apa yang diharapkan.

Pembelajaran dengan menggunakan strategi pemodelan, dapat memberikan peluang besar bagi siswa dalam mengembangkan kemampuannya untuk berkomunikasi terhadap siswa yang memiliki komunikasi interpersonal tinggi, karena strategi pemodelan menuntut siswa untuk lebih aktif dan kreatif dalam penggunaan bahasa karena siswa menyadari bahwa menggunakan bahasa dan menguasai komunikasi interpersonal akan sangat bermanfaat baginya.

Dalam penelitian ini diproleh simpulan bahwa siswa dengan komunikasi interpersonal tinggi memperoleh hasil belajar yang lebih tinggi jika dibelajarkan dengan strategi pemodelan, hal ini sesuai dengan pendapat Muhammad (2004) yang menyatakan ada beberapa tujuan dari perlunya komunikasi interpersonal pada diri seseorang. yaitu: (1) menemukan diri sendiri, salah satu tujuan komunikasi interpersonal adalah menemukan personal atau pribadi, (2) menemukan dunia luar, hanya komunikasi interpersonal menjadikan seseorang dapat memahami lebih banyak tentang dirinya dan orang lain yang berkomunikasi dengannya, (3) membentuk dan menjaga hubungan yang penuh arti, salah satu keinginan orang yang paling besar adalah membentuk dan memelihara hubungan dengan orang lain, (4) merubah sikap dan tingkah laku, banyak waktu dipergunakan untuk mengubah sikap dan tingkah laku orang lain dengan 
pertemuan interpersonal, (5) untuk bermain dan kesenangan, bermain mencakup semua aktivitas yang mempunyai tujuan utama adalah mencari kesenangan, berbicara dengan teman mengenai aktivitas kita pada waktu akhir pekan, berdiskusi mengenai olahraga, menceritakan cerita dan cerita lucu pada umumnya hal itu adalah merupakan pembicaraan yang untuk menghabiskan waktu yang tergolong sebagai komunikasi interpersonal, dan (6) untuk membantu dalam bidang tertentu, ahli-ahli kejiwaan, ahli psikologi klinis dan terapi menggunakkan komunikasi interpersonal dalam kegiatan profesional mereka. Dari ciri-ciri di atas maka strategi pemodelan sangat baik diajarkan pada siswa yang memiliki komunikasi interpersonal tinggi, karena cirri-ciri ini sangat mendukung karakteristik pembelajaran pemodelan.

\section{PENUTUP}

Berdasarkan hasil penelitian dan pembahasan yang dikemukakan sebelumnya, maka dapat simpulkan bahwa :

1. Hasil belajar Bahasa Indonesia siswa yang diajar dengan strategi pembelajaran pemodelan lebih tinggi daripada hasil belajar Bahasa Indonesia siswa yang diajar dengan strategi pembelajaran komunikatif.

2. Hasil belajar Bahasa Indonesia siswa dengan komunikasi interpersonal tinggi lebih tinggi daripada hasil belajar Bahasa Indonesia siswa dengan komunikasi interpersonal rendah.

3. Terdapat interaksi antara strategi pembelajaran dan terhadap hasil belajar Bahasa Indonesia siswa. Berdasarkan uji lanjut diperoleh hasil bahwa siswa dengan komunikasi interpersonal tinggi jika diajar dengan strategi pembelajaran Pemodelan memperolah hasil belajar Bahasa Indonesia lebih tinggi daripada dengan siswa dengan komunikasi interpersonal tinggi yang diajar dengan strategi pembelajaran Komunikatif, dan hasil belajar Bahasa Indonesia siswa dengan komunikasi interpersonal rendah yang diajar dengan strategi pembelajaran komunikatif lebih tinggi daripada siswa dengan komunikasi interpersonal rendah yang diajar dengan strategi pembelajaran pemodelan.

\section{DAFTAR PUSTAKA}

Anglin, G.J. Instructional Technologi, past, present, future. Engelwood Colorado: Librarias Unlimited, Inc.

Bandura, A. (1977). Social Learning Theory. Englewood Cliffs, New Jersey: PrenticeHall

Bandura. (1982). Self-Efficacy: The Exercise of Control. New York: W.H. Freeman and Company.

Bloom, B.S. (1985). Taxonomy of Educational Objectives. Handbook 1: Cognitive domain. New York: David McKay

Breen, M.P., Candlin, C. \& Waters, A. (1982). Communicative materials design: some basic principles. RELC Journal, 10/2.

Crain, W. (1992). The Teories of Development: Concepts and Applicatition. Englewood Cliff: Prentice Hall

Cole, G. Peter and. Chan. L.K.S. (1990). Teaching Principles and Practice. New York: Prentice Hall

Cronbach,.L., (1984). Essential of Phsycologycal Testing. New York : Harper and Row

Dahar, R.W. (1989). Teori-Teori Belajar. Jakarta: Erlangga

Dahnia, L (2010) Hubungan antara Kemampuan Bilingual dengan Keterampilan Berkomunikasi Interpersonal Pada Siswa Kelas X SMAN 4 Semarang. Jurnal Penelitian. Malang: Universitas Negeri Malang. Vol 4, No,5

Depdiknas, (2006). Peraturan Menteri Pendidikan Nasional Republik Indonesia Nomor 22 Tahun 2006 tentang Standar Isi Untuk Satuan Pendidikan Dasar dan Menengah. Jakarta: Puskur

Devito, J.A. (2002). The Interpersonal Communication Reader. New York: Allyn and Bacon.

Dick, W., Carey, L. And Carey J. O. (2005). The Systematic Design of Instruction (Edisi II). USA: Scott, Foreman.

Dimyati dan Mudjiono (1999). Belajar dan Pembelajaran, Jakarta: Rineka Cipta

Farida, N. (2006) Hubungan Sikap Siswa Pada Pergaulan Teman Sebaya dan Komunikasi Antar Pribadi Terhadap Penguasaan diri Remaja di Kelas XI SMA Teuku Umar Tahun pelajaran 20042005. Jurnal Penelitian. Semarang: Universitas Negeri Malang 
Gagne. 1979. Principles of Instructional Design, Second edition. New York: Holt Rinehart and Winston

Gredler, M.E. B. (1994). Belajar dan pembelajaran. Penerjemah: Suryana. PT Raja Grafindo Persada: Jakarta.

Gronlund, N.E. (1985). Measurement and Evaluation in Teaching. New York: Macmillan Publishing, Co.

Kaseng, S. (1989). Linguistik Terapan: Pengantar Menuju Pengajaran Bahasa Yang Sukses. Jakarta: Deaprtemen Pendidikan dan Kebudayaan

Littelwood, W. (1983). Communicative Langunge Teaching and Instruction. London: Cambridge University Press

Molina, M. (2009). "Pengaruh Strategi Pembelajaran dan Sikap Berwirausaha Terhadap Hasil Belajar Kewirausahaan Siswa SMK Negeri 8 Medan". Tesis. Medan: Pascasarjana UNIMED.

Muhammad (2004). Komunikasi Organisasi. Jakarta: Bumi Aksara.

Mulyana, D. (2002). Ilmu Komunikasi Suatu Pengantar. Bandung: Remaja Rosdakarya

Mulyasa. 2007. Menjadi Guru Profesional Menciptakan Pembelajaran yang Kreatif dan Menyenangkan. Bandung Remaja Rosdakarya.

Nababan. P.W.J. (1993). Metodologi Pembelajaran Bahasa. Jakarta: Gramedia Pustaka Utama

Nasution, S. 1982. Teknologi Pendidikan. Bandung: Jemmars

Nasution, A.S.A. (2006). Bunyi Bahasa. Jakarta: UIN Press.

Nasution, S. (1987). Berbagai Pendekatan Dalam Proses Belajar Dan Mengajar. Jakarta Bumi Aksara.

Nurhadi. 1995. Tata Bahasa Pendidikan Landasan Penyusunan Buku Pelajaran Bahasa. Semarang: IKIP Semarang Press

Nurhadi. 2004. Kurikulum 2004 Pertanyaan dan Jawaban. Jakarta: Grasindo

Purwo, .B. K. (1990). Pragmatik dan Pembelajaran Berbahasa Menyibak Kurikulum 1984. Yokyakarta: Kanisius

Rahmad, J. (2001) Psikologi Komunikasi. Bandung: Remaja Rosadakarya
Reigeluth, C.M. 1983. Instructional Design Theory of Pendekatans: An Overviuw of the their Current Status. London: Prentice Hall

Rifa'i, A. Catharina, T. 2009. Psikologi Pendidikan. Semarang: Universitas Negeri Semarang Press

Romizowski, A.Z. 1981. Designing Instructional System. New York: Nichol Publishing Company.

Sadiman, A. M. 2003, Interaksi dan Motivasi Belajar Mengajar. Jakarta : Raja Grafindo Persada

Sadtono. (1987) Antologi Pembelajaran Bahasa Asing Khususnya Bahasa Inggris. Jakarta: P2LPTK

Sanjaya, W. 2009. Strategi Pembelajaran Berorintasi Standar Proses Pendidikan. Jakarta: Kencana Prenada Media Group

Sagala, S. (2003). Konsep dan Makna Pembelajaran. Bandung: Alfabeta

Sarwono, Sarlito W. (1996). Psikologi Sosial: Individu dan Teori-Teori Psikologi Sosial. Jakarta: Balai Pustaka

Slavin, R. E. (1990) Cooperative Learning: Theory, Research and Practice. Needham Heights: Allyn and Bacon

Snellbecker, Glen E. 1974. Learning Theory Instructional Theory and Psychoeducational Design. New York: Me, Graww-Hill Inc.

Susilawati, (2005). Pengaruh Strategi Pembelajaran dan Kreativitas Terhadap Hasil Belajar PPKn Siswa SMA Kota Medan, Tesis. Medan: Pascasarjana UNIMED

Suwarna. (2002). Strategi Penguasaan Berbahasa. Yokyakarta: Adicita

Tarigan, D., dkk (2003) Pendidikan Bahasa dan Sastra Indonesia di Kelas Rendah. Jakarta: Universitas Terbuka.

Tarigan, H.G. (1984). Pengajaran Kosakata. Bandung: Angkasa

Tarigan, H.G. (1991). Metodologi Pembelajaran Berbahasa. Bandung: Angkasa

Winkel. W.S. 2007. Psikologi Pengajaran. Yokyakarta: Media Abadi. 